\title{
DISTRIBUSI MITOKONDRIA DAN EKSPRESI BAX PADA HUVEC's YANG MENGALAMI APOPTOSIS AKIBAT INDUKSI OX-LDL
}

\section{MITOCHONDRIAL DISTRIBUTION AND BAX EXPRESSION ON APOPTOTIC HUVEC'S INDUCED WITH OX-LDL}

\author{
Wibi Riawan, Samodrijanti Wibowati \\ Laboratorium Biokimia Biomolekuler Fakultas Kedokteran Universitas Brawijaya
}

\begin{abstract}
It had been revealed that endothelial dysfunction which is caused by oxydized LDL is related to TNF Receptor Apoptosis Including Ligand (TRAIL) mechanism. However, there is study to see the involvement of mitochondrial mecanism in OxLDL endothelial cells dysfunction. This study was done to see the effect of Ox-LDL treatment on apoptosis of HUVEC's culture whether associated with the distribution of mitochondria or BAX expression, the main protein mitochondria apoptosis mechanism. HUVEC's culture was divided into two groups: control group and treatment group ( $50 \mathrm{mg} / \mathrm{ml} \mathrm{Ox-}$ LDL for 24 hours). Doublestaining for DNA fragmented (TUNEL) and BAX expression were done respectively, as well as immunochemistry using monoclonal Ab of mitochondria. In the control group mitochondria was distributed firmly on cytoplasma of endothelial cells. In contrast, mitochondria were only found near nuclear membrane cells on treatment group (this future usually found on divided cells) there was also an increasing of BAX expression and a mount of apoptotic cells on treatment group compared with control group. It can be concluded that mitochondria is involved in apoptosis of Ox-LDL endothelial cells in order to serve the abundant energy.
\end{abstract}

Keywords: Mitochondria distribution, Bax expresson, Apoptotic, Ox-LDL

\section{PENDAHULUAN}

Penelitian terhadap kejadian apoptosis kultur HUVEC's akibat paparan ox-LDL telah dilakukan dan diketahui bahwa peningkatan kejadian apoptosis sel-sel endotel dengan induksi ox-LDL berasosiasi dengan aktivasi NFkB dan peningkatan ekspresi TNFa (1). Dinyatakan bahwa disfungsi endotel yang disebabkan LDL-teroksidasi pada patogenesa aterosklerosis adalah melalui aktivasi LOX-1(lectin like ox-LDL receptor). Ambilan LDL-teroksidasi melalui LOX-1 in vivo tidak menyebabkan akumulasi lipid tetapi menyebabkan aktivasi dan disfungsi sel endotel $(2,3)$. Jalur signal untuk kerusakan endotel oleh LDL-teroksidasi antara lain melalui ROS (reactive oxigen species) yang dibentuk intraseluler, aktivasi protein kinase dan faktor transkripsi. Dengan mengacu pada penelitian terdahulu, salah satunya bahwa terjadinya proses apoptosis pada sel endotel dengan paparan ox-LDL melalui jalur eksternal TRAIL (TNF Receptor Apoptosis Inducing Ligand), namun demikian pada penelitian ini dalam kerangka konsep yang sama, akan diuji keterlibatan jalur mitokondria dalam meregulasi apoptosis sel-sel endotel yang dipapar dengan ox-LDL 50ug/mL.

LDL teroksidasi (Oxidized LDL) menyebabkan aktivasi endotel dan perubahan dalam karakteristiknya. Efek

Jurnal Kedokteran Brawijaya, Vol. XXII, No.2, Agustus 2006

Korespondensi: Wibi Riawan; Laboratorium Biokimia

Biomolekuler Fakultas Kedokteran Unibraw; Jl. Veteran

Malang 65145; Telp. (0341) 569117 Pes:128 aterogenik LDL teroksidasi didapatkan dari komponen lipid yang teroksidasi.

Studi pada kultur sel menunjukkan efek proliferatif pada sel otot polos yang merupakan penyebab migrasi sel otot pada intima dan pada restenosis. Ambilan LDLteroksidasi melalui LOX-1 in vivo menyebabkan aktivasi dan disfungsi sel endotel. Superoxide anion, hydrogen peroxyde dan homosistein dapat meningkatkan ekspresi LOX-1 $(2,3)$.

Paparan radikal bebas dan radiasi, shear stress, pada pembuluh darah dapat menyebabkan peningkatan apoptosis yang lebih dini pada sel endotel (4). Posisi endotel antara jaringan dan pembuluh darah menunjang adanya paparan berkelanjutan yang mengarah pada meluasnya berbagai stimuli, beberapa diantaranya potensial untuk menginduksi apoptosis (kematian sel) pada sel endotel. Stimuli yang berbeda dengan bermacam-macam reseptor dan jalan signal transduksi, mampu mengaktifkan jalur protease (caspase) yang akan mengarah pada program perusakan selular terhadap dirinya dengan pemecahan struktur selular pada sisi yang spesifik yang terkontrol dan teratur (5).

Salah satu jalur apoptosis adalah melibatkan protein (reseptor) CD95 atau reseptor Fas (yang tergabung dalam TNF Receptor family) beserta Fas ligand, yang disebut sebagai TRAIL yang membentuk jalur menuju apoptosis dan disebut sebagai Extrinsic pathway atau juga Death Receptor Pathway (6).

Jalur apoptosis melalui TNFa ini selanjutnya akan mengaktivasi cascade yang dimediasi oleh caspase-8 
sampai akhirnya mengaktivasi caspase-3. Daneil (2004) memberikan gambaran bahwa aktivasi caspese-8 oleh Death Receptor Pathway akan mengaktivasi protein Bid, dan bahwa bahwa BAX diaktivasi oleh protein Bid maupun Bad (7). BAX berinteraksi dengan membran luar mitokondria, yang akan menyebabkan pelepasan sitokrom-c yang akhirnya akan menyebabkan apoptosis sel.

Mitokondria diketahui juga berperan dalam regulasi apoptosis. Beberapa mekanisme yang diketahui antara lain dengan lepasnya sitokrom c, hilangnya potensial transmembran mitokondria, gangguan oksidasi-reduksi sel dan peran protein, Bcl-2 baik pro dan antiapoptosis. Dinyatakan bahwa apoptosis didefinisikan sebagai suatu proses kematian sel terencana (programmed cell death), yang merupakan suatu proses yang teregulasi dan membutuhkan energi.

Pada proses apoptosis akan terjadi kerusakan membran mitokondria yang mengakibatkan lepasnya sitokrom c. Sitokrom c adalah bagian dari rantai respirasi yang berada dan larut diantara membran dalam dan membran luar mitokondria (8). Protein famili Bcl-2 yang bersifat anti-apoptosis seperti Bcl-2, Bcl-xl terletak pada membran luar mitokondria yang menghalangi apoptosis. Anggota famili $\mathrm{Bcl}-2$ yang pro-apoptosis seperti Bax dan Bad bekerja melalui membran mitokondria dengan cara berinteraksi dengan $\mathrm{Bcl}-2$ dan $\mathrm{Bcl}-\mathrm{xl}$, atau secara langsung dengan membrane mitokondria.

Faktor-faktor yang menyebabkan lepasnya sitokrom $\mathrm{c}$ dari mitokondria masih belum jelas, diduga anggota $\mathrm{Bcl}-2$ pro-apoptosis mempunyai kemiripan dengan pore forming protein dari bakteri yang menyebabkan timbulnya lubang pada membran luar mitokondria, sehingga sitokrom $\mathrm{c}$ dan apoptosis inducing factor (AIF) terlepas dari dalam mitokondria dan masuk ke sitoplasma. Sedangkan Bcl-2 dan Bcl-xl menghambat pembentukan lubang tersebut. Selain itu berbagai rangsangan juga dapat menyebabkan lepasnya sitokrom c ini, antara lain Bax, oksidan, caspase, dan kalsium yang berlebihan $(6,8)$.

\section{METODE}

\section{Sampel dan Cara Pemilihan sampel}

Sampel penelitian ini adalah sebagian umbilikus (tali pusat) yang diambil dari wanita yang partus di rumah sakit yang sesuai dengan kriteria inklusi dan eksklusi. Kriteria inklusi meliputi kehamilan fisiologis. Sedangkan yang termasuk kriteria inklusi dari penelitian ini meliputi kehamilan dengan pre-eklampsia/eklampsia, hipertensi, post date, premature rupture membrane, grande multipara, gestasional diabetes.

Isolasi dan Pembuatan Kultur Sel endotel (HUVEC's) (9)

Umbilikus dibersihkan dari darah yang ada dengan kertas tisu yang disemprot dengan alkohol $70 \%$ dan masing-masing ujung umbilikus dipotong transversal sehingga terlihat dua arteri dan satu vena. Vena akan terlihat mempunyai dinding yang lebih tebal, lebih besar dan elastis. Kemudian cannule dimasukkan pada salah satu ujung vena $( \pm 1 \mathrm{~cm})$, kemudian diikat erat dengan benang. Vena dibersihkan/dibilas dengan $10 \mathrm{ml}$ larutan PBSA melalui cannule yang telah terpasang dengan spuit $10 \mathrm{cc}$. Setelah bersih, ikat ujung umbilikus yang lain dengan ikatan yang kuat (atau diklem).

Larutan Collagenase $0,15 \mathrm{ng} / \mathrm{ml}$ dimasukkan melalui spuit dan spuit dibiarkan menancap pada cannule. Selanjutnya umbilikus diinkubasi pada suhu $37^{\circ} \mathrm{C}$ selama 7 menit. Collagenase (yang telah mengandung endotel) dikeluarkan dari umbilikus dengan cara menyedot melalui spuit yang masih terpasang pada ujung cannule. Kemudian larutan Collagenase tersebut dimasukkan pada tabung sentrifuge steril $15 \mathrm{cc}$. Umbilikus dibilas dengan $8 \mathrm{cc}$ larutan PBS A untuk membilas sel endotel yang masih tersisa. Kemudian larutan dimasukkan ke dalam tabung sentrifuge. Larutan yang telah mengandung sel endotel tersebut disentrifugasi dengan kecepatan 1000 rpm selama 8 menit. Supernatan dibuang, kemudian ditambahkan $4 \mathrm{ml}$ medium kultur pada pellet dan diresuspensi dengan cara pipetting sehingga sel-sel endotel terpisah. Larutan dipindahkan ke dalam well plate diameter $35 \mathrm{~cm}^{2}$ yang sebelumnya telah dilapisi dengan larutan gelatin $0,2 \%$, ditambahkan medium sampai $2 \mathrm{ml} /$ medium kemudian dimasukkan pada inkubator $\mathrm{CO}_{2} 5 \%$ pada suhu $37 \circ \mathrm{C}$ selama 20 menit. Well plate diambil dan sel endotel diamati dengan mikroskop inverted perbesaran 400x. Jika sel sudah menempel pada dasar well, medium kultur diambil dan sel dibilas dengan serum free medium $3 \mathrm{ml}$ melalui filter $0,2 \mu \mathrm{m}$. Serum free medium diambil dengan spuit steril dan digantikan dengan medium kultur $4 \mathrm{ml}$ melalui filter 0,2 $\mu \mathrm{m}$. Well plate dimasukkan ke dalam inkubator sampai monolayer kurang lebih 3-4 hari dan medium diganti setiap 2 hari sekali. Sel endotel ditandai dengan gambaran sel berbentuk poligonal atau cobblestone dengan inti eksentrik.

\section{Perlakuan dengan LDL teroksidasi}

Cara pembuatan larutan LDL teroksidasi: dibuat larutan stok $2 \mathrm{mg} / \mathrm{ml}$ atau $2000 \mu \mathrm{g} / \mathrm{ml}$. Untuk mendapatkan konsentrasi $50 \mu \mathrm{g} / \mathrm{ml}$ maka diambil 0,05ml oksidasi LD untuk $2 \mathrm{ml}$ volume total medium.

Untuk mengetahui efek ox-LDL terhadap BAX dan apoptosis, kultur sel endotel dipapar dengan $50 \mu \mathrm{g} / \mathrm{ml} \mathrm{LDL}$ teroksidasi kemudian setelah 24 jam diamati distribusi mitokondria, ekspresi BAX dan DNA Fragmentasi.

\section{Doublestaining DNA terfragmentasi (TUNEL) dan ekspresi BAX (imunositokimia)}

Slide dicuci menggunakan PBS $\mathrm{pH} 7,4$ dan diinkubasi menggunakan $20 \mathrm{ug} / \mathrm{mL}$ proteinase-K selama 15 menit pada $37^{\circ} \mathrm{C}$. Dicuci menggunakan PBS pH 7,4 tiga 
kali, masing-masing selama 5 menit. Diinkubasi pada 3\% $\mathrm{H} 2 \mathrm{O} 2$ selama 15 menit dan selanjutnya dicuci dengan PBS pH 7,4 tiga kali, masing-masing selama 5 menit. Diinkubasi dengan Tunel fragmented DNA labelling selama 60 menit pada $37^{\circ} \mathrm{C}$. Dicuci menggunakan PBSpH 7,4 tiga kali, masing-masing selam 5 menit. Diinkubasi dengan Peroksidase solution selama 40 menit pada $37^{\circ} \mathrm{C}$. Dicuci menggunakan PBSpH 7,4 tiga kali, masing-masing selama 5 menit. Ditetesi menggunakan substrat untuk Peroksidase (DAB - Diamino Benzidine) selama 20 menit pada suhu ruang. Dicuci menggunakan PBSpH 7,4 tiga kali, masingmasing selama 5 menit. Bloking unspesifik protein menggunakan 5\% FBS yang mengandung 0,25\% Triton X100. Dicuci menggunakan PBSpH 7,4 tiga kali, masingmasing selama 5 menit. diinkubasi menggunakan mouse monoclonal anti BAX (human absoorbed) semalam pada suhu $4^{\circ} \mathrm{C}$. Dicuci menggunakan PBS pH 7,4 tiga kali, masing-masing selama 5 menit. diinkubasi menggunakan anti mouse AP conjugated selama satu jam pada suhu ruang. Dicuci dengan PBS pH 7,4 dan diinkubasi pada substat untuk AP, Fast Red selama 30 menit. Dicuci dengan PBS pH 7,4 dan Counterstain dengan Mayer hematoxilen selama 10 menit, dibilas dengan air kran dan dicuci dengan $\mathrm{dH} 2 \mathrm{O}$. Dikeringkan dan ditutup coverglass. Kemudian diamati dibawah mikroskop cahaya dengan pembesaran 1000x, sel-sel apoptosis ditunjukkan dengan warna coklat pada inti sel sedangkan ekspresi BAX dutunjukkan dengan warna merah pada sitoplasma sel.

\section{Imunositokimia terhadap mitokondria}

Slide dicuci menggunakan PBS pH 7,4 satu kali selama 5 menit. Bloking endogenous peroksida menggunakan 3\% H2O2 selama 20 menit. Dicuci menggunakan PBSpH 7,4 tiga kali, masing-masing selam 5 menit. Bloking unspesifik protein menggunakan 5\% FBS yang mengandung $0,25 \%$ Triton $\mathrm{X}$-100 dicuci menggunakan PBSpH 7,4 tiga kali, masing-masing selama 5 menit.

Diinkubasi menggunakan mouse monoclonal anti mitokondria semalam pada suhu $4^{\circ} \mathrm{C}$. Dicuci menggunakan PBS pH 7,4 tiga kali, masing-masing selama 5 menit. Diinkubasi menggunakan anti mouse conjugated selama satu jam pada suhu ruang. Dicuci menggunakan PBSpH 7,4 tiga kali, masing-masing selam 5 menit. Diinkubasi menggunakan SA-HRP (Strep-Avidin Horse Radis Peroxidase) selama 40 menit. Dicuci menggunakan PBSpH 7,4 tiga kali, masing-masing selama 5 menit. Ditetesi dengan DAB (Diamino Benzidine) dan diinkubasi selama 10 menit. Dicuci menggunakan PBSpH 7,4 tiga kali, masingmasing selama 5 menit. Counterstaining menggunakan Mayer Hematoxilen yang diinkubasi selama 10 menit dan dicuci menggunakan tap water. Dibilas menggunakan $\mathrm{dH} 2 \mathrm{O}$ dan dikering anginkan. Mounting menggunakan entelan dan ditutup dengan cover glass dan dilakukan pengamatan pada mikroskop cahaya.

\section{HASIL PENELITIAN}

Ekspresi BAX dan Apoptosis dan Distribusi Mitokondria Sel Endotel Kultur HUVEC's yang dipapar dengan oxLDL 50ug/mL.

Dinyatakan bahwa paparan ox-LDL 25ug/mL dan 50 $\mathrm{ug} / \mathrm{mL}$ mengakibatkan peningkatan apoptosis sel-sel kultur HUVEC's, yang disertai dengan aktivasi faktor transkripsi NFkB dan eksperesi TNF $\llbracket$, dalam kaitan tersebut, bahwa jalur apoptosis ditengarahi melalui death receptor, TNF $\llbracket R$ (1). Namun demikian, bahwa kejadian apoptosis merupakan cascade proses yang melibatkan berbagai faktor yang saling terkait atau mengaktifkan. Pada penelitian ini, sejalan dengan penelitian terdahulu bahwa terjadi peningkatan kejadian apoptosis kultur HUVEC's yang dipapar dengan ox-LDL meningkat pada perlakuan ox-LDL $50 \mathrm{ug} / \mathrm{mL}$. (Gambar 1B) Beberapa aspek dari apoptosis pada sel, dapat dikarakterisasi melalui morfologi seluler yang dapat diamati pada mikroskop electron, meliputi shrinkage, migrasi kromatin dan membrane blebbing, kondensasi inti serta kemudian segmentasi dan pemisahan menjadi apoptostic bodies (yang akan mengalami fagositosis). Fragmentasi DNA yang terjadi pada proses apoptosis akan berlangsung selama beberapa jam, sebelum akhirnya akan mengalami proses fagositosis.

DNA yang mengalami fragmentasi dapat dideteksi secara enzimatis dengan labeling ujung 3'-OH, dengan menggunakan digioxigenin enzim maka dapat diamati kejadian fragmentasi DNA - yang merupakan poin dari proses apoptosis. Pada penelitian ini peningkatan kejadian apoptosis pada kultur HUVEC's yang dipapar dengan oxLDL diikuti dengan peningkatan ekspresi BAX. (Gambar 1B) tampak bahwa sitoplasma sel endothel berwarna merah, yang merupakan visualisasi cromogen Fast-Red.

Komplek antigen-antibodi (BAX intraseluler berikatan dengan antibodi BAX) dan kemudian antibodi juga membentuk komplek dengan antibodi sekunder yang membawa label biotin. Biotin disini membawa label alkaline phosphatase (AP), yang merupakan enzim, yang jika bereaksi dengan substratnya (Fast Red) akan membentuk cromogen/warna merah, yang merupakan interpretasi dari jumlah/banyaknya protein BAX seluler. Sehingga dalam penelitian ini sangat perlu untuk dilihat distribusi mitokondria, sebagai kunci jalur internal pada apoptosis.

Dari hasil pewarnaan menggunakan imunositokimia terhadap mitokondria dengan menggunakan antibodi spesifik terhadap mitokondria tampak bahwa terjadi perbedaan distribusi mitokondria. Pada kelompok kontrol, tampak bahwa mitokondria terdistribusi merata pada sitoplasma sel (Gambar 2, Panel A, tanda panah warna hitam) dan hal ini berbeda dengan kelompok paparan oxLDL $50 \mathrm{ug} / \mathrm{mL}$ dimana tampak bahwa mitokondria terdisribusi mendekati membran inti sel (Gambar 2, Panel 
B, tanda panah warna kuning). Dalam penelitian ini, juga didapati gambaran distribusi mitokondria pada kejadian sel yang sedang melakukan pembelahan (Gambar 2, Panel A,
B dan $\mathrm{C}$, tanda panah warna biru), yang mirip dengan kelompok paparan ox LDL 50ug/mL bahwa mitokondria terdistribusi mendekati membran inti sel.
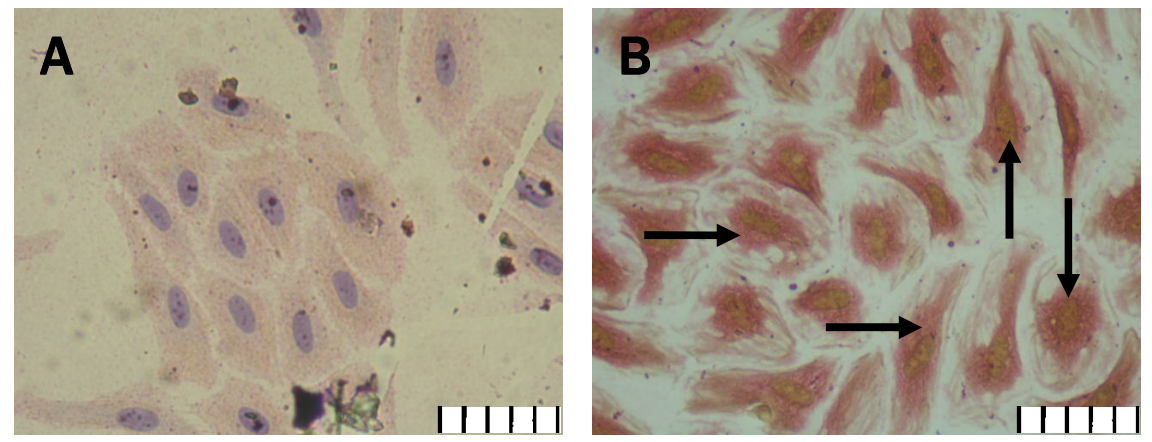

Gambar 1. Distribusi BAX (warna merah pada sitoplasma sel yang ditunjukkan oleh panah berwarna biru) menunjukkan terjadi peningkatan ekspresi BAX pada perlakuan menggunakan ox-LDL 50ug/mL. Tampak juga terjadi peningkatan kejadian apoptosis (warna coklat pada inti sel ditunjukkan oleh panah berwarna hitam), kontrol (A) pada perlakuan menggunakan ox-LDL 50ug/mL (B).

PANEL A

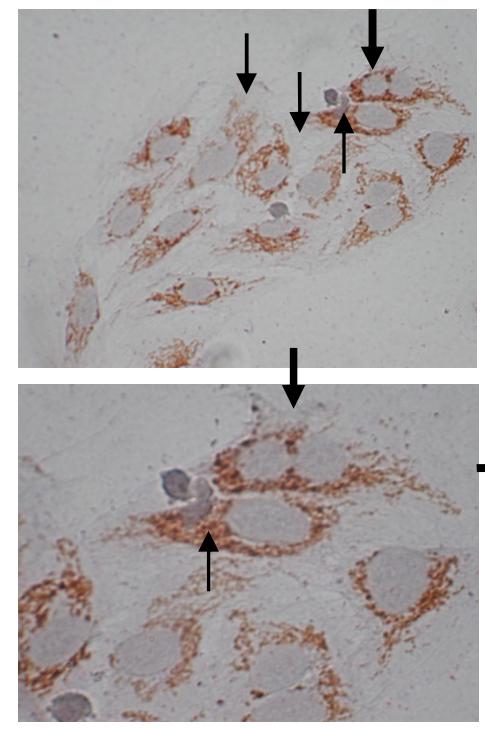

PANEL B
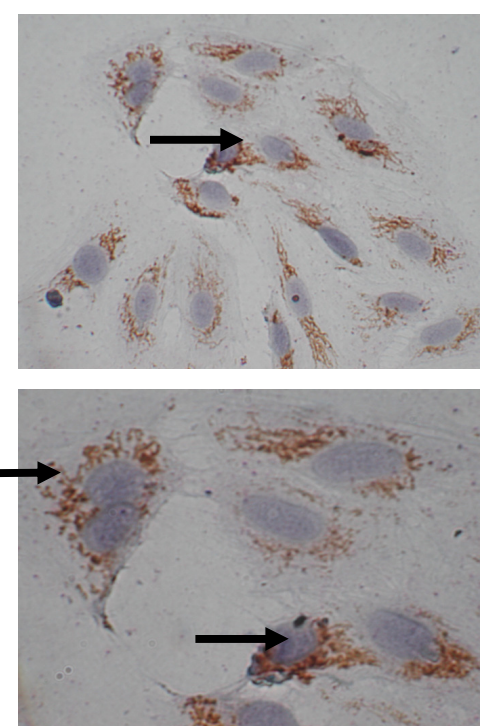

PANEL C
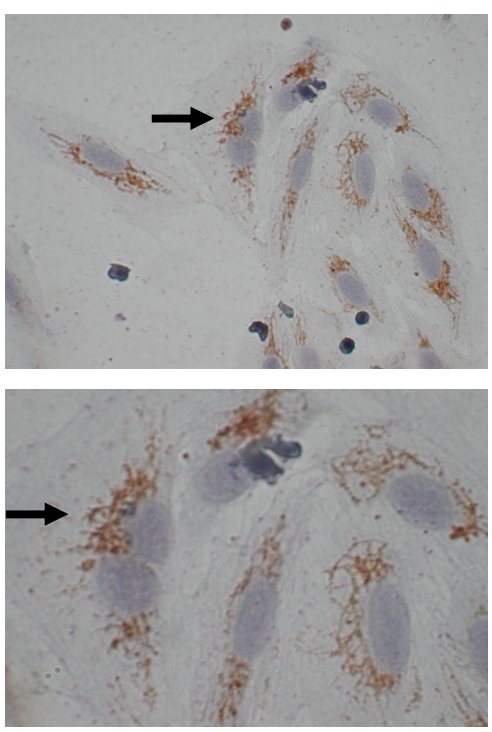

Gambar 2. Gambaran Distribusi Mitokondria Kultur HUVEC's yang dipapar ox-LDL. Pada kelompok kontrol (PANEL-A) mitokondria tampak menyebar pada sitoplasma sel (tanda panah berwarna hitam) dan akan tampak berbeda dengan kelompok paparan ox-LDL 50ug/mL (PANEL-B) yang menunjukkan sebaran mitokondria terkumpul mendekati membran inti sel (panah berwarna kuning) dan hal ini akan tampak sama dengan gambaran mitokondria pada sel-sel yang sedang melakukan pembelahan (panah berwarna biru), dimana mitokondria akan terkumpul mendekati membran inti sel (PANEL-A, PANEL-B, PANEL-C).

\section{DISKUSI}

Apoptosis didefinisikan sebagai suatu proses kematian sel terencana (programmed cell death), yang merupakan suatu proses yang teregulasi dan membutuhkan energi. Hal ini membedakan apoptosis dari nekrosis, suatu proses yang sama-sama menghasilkan kematian sel, namun keduanya berbeda dalam hal morfologis dan regulasi struktur seluler (10). Nekrosis terjadi dengan dicirikan adanya proses kehilangan (loss) yang cepat pada proses homeostasis sel, proses pembengkakan yang cepat oleh karena akumulasi air dan eletrolit, ruptur membran awal, dan terjadinya "leakage" dari material sel keluar sel. Terjadinya nekrosis sel menginduksi terjadinya reaksi inflamasi (10). Nekrosis umumnya melibatkan sekelompok 
sel secara bersama-sama yang terjadi oleh karena clinical insult yang berat (6).

Proses apoptosis dicirikan dengan terjadinya pengerutan sel dan nukleus yang telah terprogram jangka waktunya. Kromatin nukleus pada proses apoptosis mengalami kondensasi, yang kemudian pecah. Pecahan ini kemudian dibungkus dalam suatu vesikel, disebut sebagai apoptotic bodies, yang mengandung pula sisa-sisa organel sel dan fragmen DNA lain, untuk selanjutnya difagositosis baik oleh sel-sel tetangganya maupun mengalami degradasi otomatis. Sekilas proses ini memiliki kemiripan dengan nekrosis sehingga sering disebut sebagai nekrosis sekunder, namun pada apoptosis tidak terjadi ruptur membran plasma (11). Proses apoptosis ini tidak menginduksi terjadinya reaksi inflamasi, namun prosesnya diinduksi oleh reaksi inflamasi sebelumnya (10). Pada umumnya apoptosis terjadi pada sel secara individuil (6).

Jalur apoptosis, menurut Husada (2004), salah satunya melibatkan protein (reseptor) CD95 atau reseptor Fas (yang tergabung dalam TNF Receptor family) beserta Fas ligand, yang disebut sebagai TRAIL yang membentuk jalur menuju apoptosis dan disebut sebagai Extrinsic pathway atau juga Death Receptor Pathway (6). Hal ini dibedakan dengan Mitochondrial pathway yang disebut juga sebagai Intrinsic Pathway. Kedua pathway di atas masih melibatkan caspase dalam prosesnya.

Dalam penelitian ini didapat bahwa dengan menggunakan pewarnaan spesifik terhadap BAX menunjukkan peningkatan ekspresi BAX pada kultur HUVEC's yang mendapatkan paparan ox-LDL 50ug/mL, yang dengan pewarnaan untuk DNA terfragmentasi pada sel yang sama (teknik doublestaining) menunjukkan juga terjadi apoptosis, dan hal ini menunjukkan bahwa kejadian apoptosis dengan induksi ox-LDL juga melibatkan protein BAX. Diketahui bahwa jalur apoptosis melibatkan BAX $(B c / 2$ family) merupakan protein proapoptisis yang akan berinteraksi dengan $\mathrm{Bcl}-\mathrm{xl}$ atau berikatan secara langsung dengan membran luar mitokondria sehingga terjadinya pelepasan sitokrom-c, yang akan bersama dengan Apaf-1, procaspase- 9 dan ATP membentuk apoptosome, yang akan mengaktifkan jalur apoptosis internal (8).

Secara jelas, Husada (2004) memaparkan bahwa Bax yang diaktifkan oleh Bid menyebabkan terjadinya Permeability Transition Pore (PTP) pada membran luar mitokondria menjadi terbuka sehingga sitokrom-c bisa bocor dengan akibat apoptosis (6). Protein (Bcl-2 dan $\mathrm{Bcl}-\mathrm{xL}$ ) mampu mencegah terjadinya PTP ini. Protein (Bax) dapat bekerja dengan membuka saluran $\mathrm{Ca} 2+$ atau menghambat Bcl-2 sehingga membuat efek anti-apoptotik Bcl-2 terhalang, demikian pula Bad menghambat Bcl-xL. Kerusakan DNA terjadi karena beberapa faktor, antara lain: AlF (Apoptosis Inducing Factor) yang terletak di intermembran mitokondria, bocor keluar oleh karena pecahnya membran mitokondria kemudian memasuki nukleus dan menimbulkan kerusakan, aktifnya berbagai endonuclease, di antaranya Endonuclease G, PARP (PolyADP Ribose Polimerase) memicu kematian sel via apoptosis dengan menempuh berbagai jalur (pathways) (6).

Dengan tampaknya peningkatan ekspresi BAX pada proses apoptosis oleh karena induksi ox-LDL, memberikan bukti keterlibatan mitokondria dalam kejadian apoptosis tersebut. dan bahwa pada penelitian terdahulu (1), dengan kerangka kosep yang sama, didapatkan hasil peningkatan ekspresi TNFa pada kultur HUVEC's yang mendapatkan paparan ox-LDL yang mengindikasikan bahwa kejadian apoptosis melibatkan TRAIL pathway. Sehingga diduga bahwa terjadi sinergitas antara TRAIL pathway dengan mitochondria pathway, hal ini sesuai dengan penelitian Daniel (2004) bahwa jalur apoptosis melalui mitokondria yang dimediasi oleh BAX (Bcl2 family), yang mana bahwa BAX diaktivasi oleh protein Bid maupun Bad (7). Bad diaktivasi melalui jalur eksternal (death receptor) melalui caspase-8. BAX berinteraksi dengan membran luar mitokondria, yang akan menyebabkan pelapasan sitokrom-c yang akhirnya akan menyebabkan apoptosis sel.

Penelitian ini juga membuktikan keterlibatan mitokondria secara struktural, yang memberikan dugaan merupakan usaha mitokondria dalam meregulasi energi yang diperlukan oleh sel dalam proses apoptosis. Dinyatakan bahwa apoptosis didefinisikan sebagai suatu proses kematian sel terencana (programmed cell death), yang merupakan suatu proses yang teregulasi dan membutuhkan energi. Mitokondria merupakan salah satu organela yang sangat penting dalam regulasi energi intraseluler $(12,13)$.

Oleh karena mitokondria memiliki VDAC (voltagedependent anion channel) berada pada outer membrane mitokondria dan membentuk pore yang berisi $\mathrm{H} 2 \mathrm{O}$ (diameter 2.5-3.0 nm) dilewati oleh larutan yang berasal dari sistem transport inner membrane mitokondria Adenine nucleotide translocase (ANT).

Terdapat pada inner membrane yang memperantarai ADP-ATP exchange, yang penting untuk fungsi bioenergetik organela dalam mengeksport ATP ke sitosol (13). Dalam proses apoptosis terjadinya fragmentasi DNA oleh aktifnya berbagai endonuclease, di antaranya Endonuclease G, PARP (Poly-ADP Ribose Polimerase) yang memicu kematian sel via apoptosis memerlukan energi yang tinggi (6). 


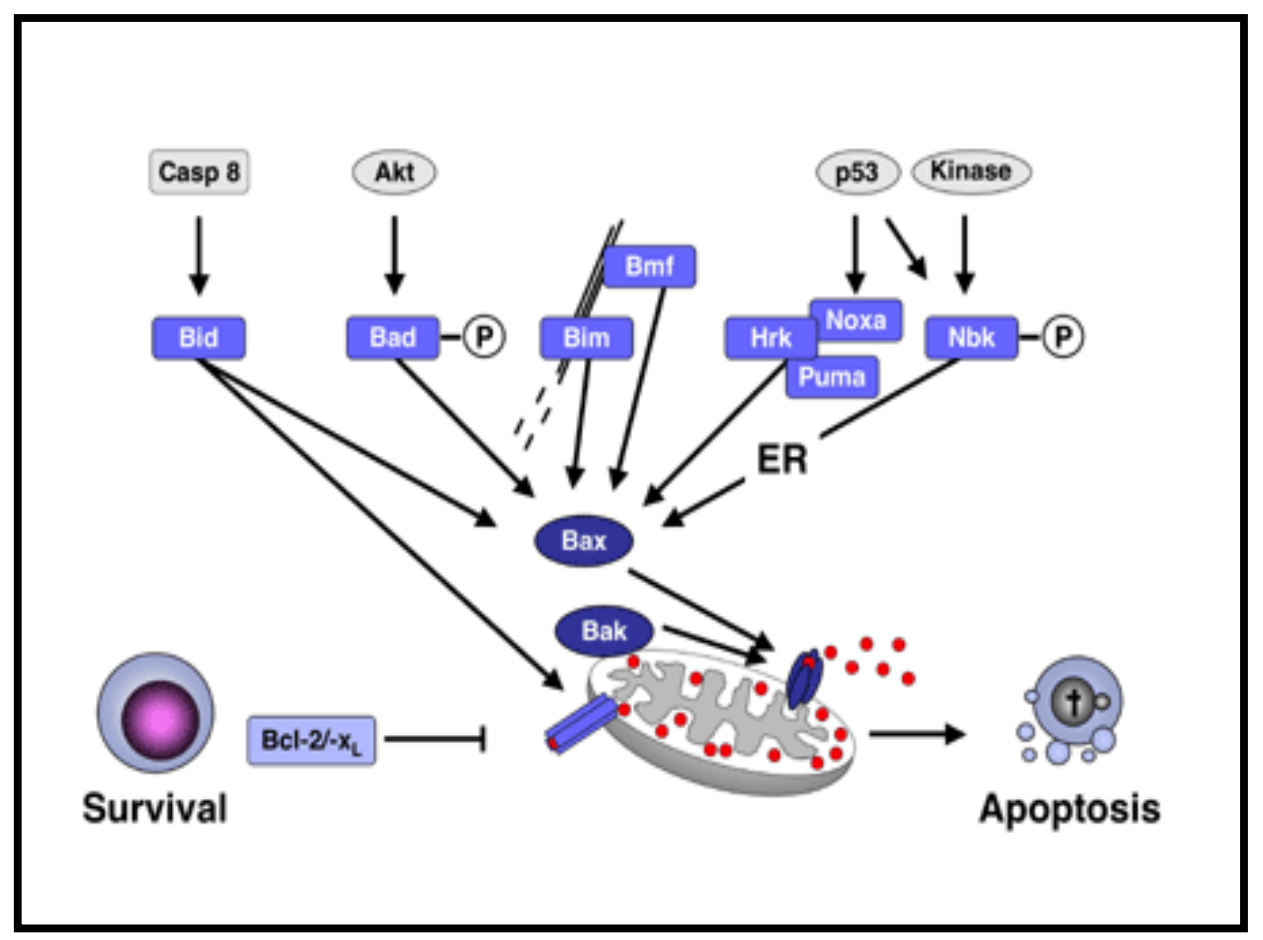

Gambar 3. Jalur Apoptosis melalui Mitokondria yang dimediasi oleh BAX (Bc/2 family), bahwa BAX diaktivasi oleh protein Bid maupun Bad yang diaktivasi melalui jalur eksternal (death receptor) melalui caspase-8. BAX berinteraksi dengan membran luar mitokondria, yang akan menyebabkan pelapasan sitokrom-c yang akhirnya akan menyebakan apoptosis sel (7).

\section{KESIMPULAN}

Dapat disimpulkan bahwa jalur mitokondria terlibat dalam proses disfungsi endotel paparan ox-LDL, hal ini merupakan usaha sel dalam rangka penyediaan energi sebagai keperluan apoptosis. Fakta yang serupa juga didapatkan pada sel endothel yang melakukan proses pembelahan.

\section{DAFTAR KEPUSTAKAAN}

1. Riawan W, Wibowati S. Pengaruh Pemberian ox-LDL terhadap Aktivasi NF-KB dan PPARy serta Apoptosis pada Kultur HUVEC's. Journal Kedokteran Brawijaya 2006; 23-29.

2. Kita T, LOX-1. A Possible Clue to The Missing Link Between Hypertension and Atherogenesis. Circ res 1999; 84:11131115.

3. Mehta J. The role of LOX-1, A Novel Lectin Like Receptor for Oxidized LDL, in Atherosclerosis. Can J Cardiol 2004;20:32B-36B.

4. Dimmeler S. Upregulation of Superoxide Dismutase and Nitric Oxide Synthase Mediates The Apoptosis-Suppressive Effect of Shear Stress on E. cells. University of Wizbury. Germany; 1999.

5. Stefanec T. Endothelial Apoptosis. Chest 2000; 117 : 841-854.

6. Husada, J.J. The Role of Apoptosis in Brain Injury. Simposium Neuro Intensif Quality Hotel, Solo. 9-10 Oktober 2004.

7. Daniel, P. Regulation of cell death by pro-apoptotic Bcl-2 family members, Clinical and Molecular Oncology Program, USA; 2004.

8. Green DG and JD Reed. Mitochondrial and Apoptosis. Science 1998; 281 : 1309-12.

9. Freshney I. Culture of animal cell: a manual of basic technique. 2eds. New York: Alan R Liss Inc ; 1987

10. Krijnen PAJ, R Nijmeijer, CLJM Meijer, CA Veisser, CE Hack, HWM Niessen. Apoptosis in myocardial Ischemia and Infarction. Journal of Clinical Pathology 2002; 55 : 801-811

11. Gauthier, Eric. Cell Death: The Basic Mechanism. Apo Review Journal 2004;82 (3). 
12. Carafoli E, Chiesi M, Gazzotti P. The Membrane carriers related to intracellular calcium regulation, Hypertension : Pathophysiotogy, Diagnosis and Mannagement 1990; 62:978.

13. Crompton M. The mitochondrial permeability transition pore and its role in cell death, Biochem 1999;(J.341): $233-249$. 